\title{
Limiting factors of face shield use for health professionals during the COVID-19 pandemic
}

\author{
Ana Cristina de Oliveira e Silva ${ }^{\mathrm{a}}$, Wynne Pereira Nogueira ${ }^{\mathrm{b}}$, Elucir Girc $^{\mathrm{c}}$, \\ Sandra Aparecida de Almeida ${ }^{\mathrm{d}}$, Bárbara Iansã de Lima Barroso ${ }^{\mathrm{e}, *}$ \\ and Maria Eliane Moreira Freire ${ }^{\mathrm{a}}$ \\ ${ }^{a}$ Department of Clinical Nursing, Federal University of Paraíba, João Pessoa, Paraíba, Brasil \\ ${ }^{\mathrm{b}}$ Post-Graduate Nursing Program, Federal University of Paraíba, João Pessoa, Paraíba, Brasil \\ ${ }^{\mathrm{c}}$ Ribeirão Preto College of Nursing, University of São Paulo, Ribeirão Preto, São Paulo, Brasil \\ ${ }^{\mathrm{d}}$ Department of Nursing in Collective Health, Federal University of Paraíba, João Pessoa, Paraíba, Brasil \\ e Occupational Therapy Department, Federal University of Paraíba, João Pessoa, Paraíba, Brasil
}

Received 13 April 2021

Accepted 25 June 2021

\begin{abstract}
.
BACKGROUND: Coronavirus disease (COVID-19) is caused by SARS-COV2, a highly transmissible and pathogenic viral infection, and was identified in December 2019 in Wuhan, China. Three months later, it became a severe pandemic.

OBJECTIVE: To identify scientific evidence on the use of face shields by health professionals during the COVID-19 pandemic period.

METHOD: An integrative literature review of articles obtained from PubMed, Cumulative Index to Nursing and Allied Health Literature (CINAHL), and Web of Science databases was undertaken. For the search, controlled, non-controlled descriptors and specific keywords: "face shield," "fluid resistance procedure," "respiratory infections," "healthcare workers," "COVID-19," "aerosols," and "personal protection infection" were used.

RESULTS: The sample comprised seven studies. The available evidence has shown that face shields do not have a defined standard for their production - their effectiveness depends on the quality of the visor, structure, and fixation system. They must be used as adjuvants to other personal protective equipment (PPE), and their isolated use is not recommended due to the fragilities of peripheral face sealing, especially during the COVID-19 pandemic period.

CONCLUSION: Due to the shortage of this equipment, domestic face shields can be indicated if they meet production requirements, based on scientific evidence for their efficient use.
\end{abstract}

Keywords: Coronavirus infections, occupational safety and health, infectious diseases, personal protective equipment, workers

\section{Introduction}

COVID-19 is a highly transmissible and pathogenic viral infection caused by the severe acute respiratory syndrome virus (SARS-CoV-2). It was

\footnotetext{
*Address for correspondence: Bárbara Iansã de Lima Barroso, Center for Health Sciences, Laboratory of Health, Labor and Ergonomics, 2 floor, Department of Occupational Therapy, Federal University of Paraíba, University Campus I, University City, João Pessoa, PB, Brazil. Zip Code: 58059-900. E-mail: barbarabarroso@yahoo.com.br.
}

identified in December 2019 in Wuhan, China, and three months later it became a severe pandemic [1].

In May 2021, one year since the declaration of a pandemic, the disease has caused more than 170 million confirmed cases and more than 3 million deaths worldwide. In the same period, Brazil registered $16,624,480$ confirmed cases with 465,199 deaths and a fatality rate of $2.8 \%$ [2]. The Ministry of Health in Brazil recommends that places with an incidence coefficient $50 \%$ higher than the estimated national level must maintain non-pharmacological measures 
until the supply of equipment (beds, PPE, respirators, and laboratory tests) and health teams are available in sufficient numbers, to safely promote the transition to the strategy of selective social detachment as described in the preparation and response according to each epidemic interval [2].

Non-pharmacological measures such as increased social distancing, selective, and lockdown, are recommended because person-to-person transmission occurs mainly through direct contact or by droplets spread by coughing or sneezing from an infected individual. However, aerosol transmission is also possible in cases of prolonged exposure to high aerosol concentrations indoors. Analysis of data related to the spread of COVID-19 in China seems to indicate that proximity between individuals is necessary for the infection to spread. In fact, dissemination is mainly limited to close contacts, family members, and health professionals [3].

Health professionals are at a much higher risk of infection than the general population, mainly due to their direct contact with infected patients. In addition, factors such as inadequate prevention measures, ineffective control, the shortage and inadequate use of PPE, and long working hours due to the reduced number of professionals, are possible explanations for the higher infection rate in this specific group [4].

Regarding protection mechanisms, the World Health Organization (WHO) recommends the use of PPE. These protection mechanisms include surgical masks, N-95 masks, gloves, appropriate clothing, glasses, and face shields for all health professionals exposed to transmissible pathogens. In relation to the prevention of infection by COVID-19, PPEs should be used according to the levels of health care, and these recommendations are based on current evidence of the mechanisms of transmission of the respective causal agent [5].

We emphasize that the faces of health professionals were reported to be the part of the body most commonly affected by droplets, aerosols, and splashes of body fluids. Thus, the face shield is classified as a PPE that provides barrier protection for the facial area and related mucous membranes such as the eyes, nose, and lips. Its use is recommended in association with other PPEs such as N-95 masks, as it should not be used alone, which explains its classification as an adjuvant to PPEs [5].

In the midst of the COVID-19 pandemic, the shortage of PPE has led health authorities to seek viable alternatives to meet this emerging need. Consequently, researchers from around the world have begun producing household face shields in an attempt to meet the growing demand for PPE [6].

Accurate data on the production of face shields, technical specifications, and the correct use of PPEs during a pandemic period are essential to encourage efficient protection. However, there is a lack of data to guide decisions based on scientific evidence to make efficient PPEs for use by health professionals in pandemic control.

In light of the importance of seeking information about the use of face shields by health professionals and considering their applicability, the present study consists of an integrative review that aims to identify scientific evidence on the use of face shields for health professionals during the COVID-19 pandemic period, to assist in the selection and proper use of this type of equipment.

\section{Method}

An integrative literature review (ILR) descriptive research was carried out. This enabled a comprehensive and methodologically rigorous analysis of the literature. In addition, it enabled analyzing and synthesizing scientific knowledge about the object of the study through the results of previous research, as well as identifying gaps that must be filled by conducting new studies [7].

The integrative review followed the fulfillment of essential steps for its development. These steps included the identification of the theme and selection of the research question, the establishment of eligibility criteria, an identification of studies in scientific databases, an evaluation of selected studies and a critical analysis, a categorization of studies, an evaluation and interpretation of the results, and presentation of data in the integrative review framework [7].

Considering the methodological rigor required for review studies and in accordance with EvidenceBased Practice (EBP), which provides for the identification of evidence contained in investigations carried out that can be incorporated into clinical practice, the use of the PICOT strategy was recommended. PICOT is an acronym with its letters referring to Patient or Problem, Intervention, Comparison, Outcomes, and Types of study, which made it possible to prepare the research question and search strategies [8].

Thus, the initial step for this integrative review was to prepare a guiding question based on the PICOT format. To formulate a guiding question the following 
Table 1

Search strategies in the Web of Science, CINAHL, and PubMed databases

\begin{tabular}{llc}
\hline Databases & Search strategy & $\begin{array}{c}\text { Publications } \\
\text { identified }\end{array}$ \\
\hline Web of Science & ALL = (personal protection infection AND face shield AND Hospital) [key word and MeSH] & 20 \\
& ALL = (personal protection infection AND (face shield OR facial protection)) [key word and MeSH] & 27 \\
CINAHL & AB = (face shield AND Healthcare workers AND COVID-19 [key word and MeSH] & \\
& AB = (hospital workers AND personal protection infection AND COVID-19) & 46 \\
& TS = (face shield* Near (protection or "personal protection infection") & \\
& AB = (face shield* OR fluid resistance procedure AND respiratory infections) [key word and MeSH] & \\
& ALL = (face shield* OR fluid resistance procedure AND Aerosols) [key word and MeSH] &
\end{tabular}

Source: Research data, 2020.

elements were explored as: $\mathrm{P}$ (health professionals in hospital services during the COVID-19 pandemic), I (selection and proper use of face shields), C (different types of face shields), and $\mathrm{O}$ (effective face shields). The final guiding question was "What scientific evidence exists on the use of face shields for health professionals during the COVID-19 pandemic period, which assists in the selection of the most effective face shield and the proper use of this type of PPE?"

Faced with the emergence of alternative and safe measures for protection against exposure to pathogens that cause respiratory infections, represented by the COVID-19 pandemic, a systematic search for recent studies addressing the use of face shields was imperative. It is noteworthy that there was no time available for the refinement of this review, justified by the scarcity of studies regarding the proposed objective. In addition, this was the maximum number of available studies.

To compose the corpus of the research, articles were searched for on the Internet in March 2020. The search in the literature of primary studies was conducted via the Internet in the following databases: PubMed, CINAHL, and Web of Science. To ensure a wide and careful search, keywords and descriptors were delimited in the Thesaurus according to the Medical Subject Headings (MeSH) database. The same applied to the guiding question raised. Boolean operators "AND" and "OR" were used. For search refinement, the symbol * was used to truncate the descriptor "face shield," as shown in Table 1. To avoid bias in the search and selection of articles, two researchers acted independently.

To select the sample, the following inclusion criteria were used: articles from primary sources indexed in the databases selected for the study, which addressed the theme in Portuguese, English, or Spanish and available in full text versions. The exclusion criteria were as follows: "being a review article," and

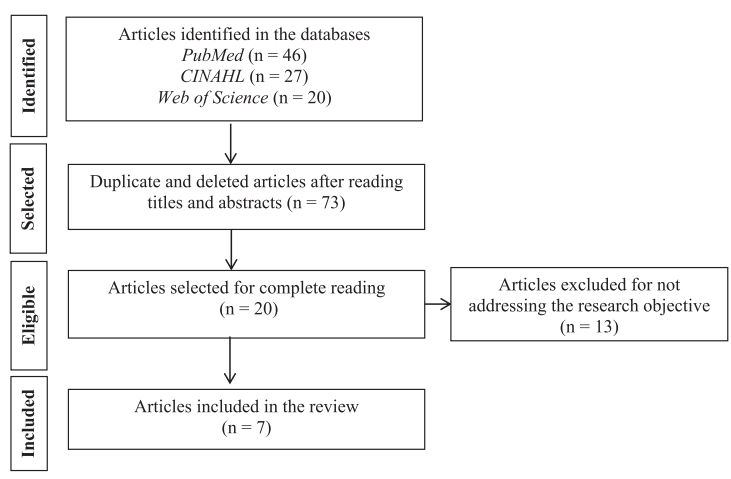

Fig. 1. Flowchart for search and selection of articles adapted from Preferred Reporting Items for Systematic Reviews and MetaAnalysis [9].

"not presenting the keywords in the title or in the summary of the selected articles." It should be noted that duplicate studies were considered only once.

The search resulted in 93 articles, of which 73 were excluded due to duplication within and between the CINAHL, PubMed, and Web of Science databases, and for not presenting the descriptors in the title or abstract. After reading the full text of 20 articles, 13 were excluded because they did not fit the objectives proposed in this integrative review. Thus, the corpus of this review comprised seven articles, whose potential content was dedicated to investigating the use of adjuvant face shields for respiratory protection to control pandemic infections. The search process followed the recommendations of the Preferred Reporting Items for Systematic Reviews and Meta-Analysis (PRISMA) [9], as shown in Fig. 1.

After the article selection stage, the full texts were read, followed by a critical analysis by two researchers, which made it possible to categorize the studies.

The results were presented descriptively by means of a summary table. The purpose of highlighting the data was considered relevant for analysis. Data were 
collected from the selected studies, including year of publication, title, objective, type of study, level of evidence of the articles and results found, followed by the analysis and interpretation of the results [10].

Due to the need to expand the search for technical and production information related to the use of face shields as PPE against infections, non-indexed/ published productions available in gray literature were used. They were conceptualized as texts that did not have an impact factor and were not formally published in sources such as books or scientific journals [8]. Therefore, editorials, guides, technical reports, and research letters were included in this review.

\section{Results}

After conducting the search across the databases and selecting the studies, the sample consisted of seven articles [11-17], which are presented in Table 2. It was observed that most articles (four publications) were published in 2019 , followed by 2014,2013 , and 2006, with one publication each.

Regarding the type of study, most of the articles presented prospective and cross-sectional descriptive observational studies, with two articles each. Randomized, non-randomized clinical trials and cohort studies resulted in one article each. Regarding the levels of evidence of the selected studies, three articles were level IV, two were level VI, and levels II and III resulted in one article each [10].

The aims of the studies were related to the adherence of health professionals to the use of PPE, the use of PPE against infections, and the exposure of professionals to aerosols with the use of PPE, all with the inclusion of face shields among the protective equipment used.

\section{Discussion}

Droplets and aerosols of body fluids from infected patients can be inhaled if they are deposited on the non-integrating skin or on the mucous membranes of the mouth, nose, or eyes. Once there, they can infect healthcare professionals and cause disease. Face shields provide a barrier to aerosols from the acute expulsion of body fluids and are commonly used as an alternative to goggles, as they provide protection to a larger area of the face [5-11].

However, although the requirement of wearing a face shield or goggles while performing procedures is well established, the need for such equipment to protect healthcare professionals during routine care of patients with respiratory infections is a subject of debate. It requires the monitoring of normative production and includes measures to protect the health and safety of workers. Current guidelines in the face of the COVID-19 pandemic explicitly recommend the use of a face shield or goggles during all forms of care of a suspected or confirmed patient in a hospital environment $[3,18]$.

Faced with the SARS-CoV-2 pandemic, the WHO has urged all countries to increase their domestic PPE production by $40 \%$. Without secure supply chains, the risk to health professionals worldwide is real. The production of face shields has exceeded the limits of medical industries and research institutes. Currently, there are different professionals producing and selling domestic face shields on a large scale in hospitals and other healthcare facilities [6].

There is an urgent need for efficient pandemic response actions, which are associated with greater security for workers who are at the forefront of various levels of healthcare. Based on the above, it is the responsibility of worker protection services, professional regulation sectors' class councils, and regulatory standards of each country to judge the face shield-type that meets recommended protection needs. It must be noted that these are adjuvant to the respiratory protection for workers who care for patients with respiratory infections. Thus, face shields cannot be used as a substitute for respiratory protection; their use, accompanied by an N-95 mask and/or a surgical mask is indisputable, and indispensable $[12,19]$.

Different studies have identified that many face shields used by healthcare professionals exhibit splashes of blood or other fluids, and that this contamination is often overlooked. However, face shields are less effective against smaller particles, which can remain in the air for long periods and can easily flow around a face shield to be inhaled. This fact justifies their use in conjunction with N-95 or PFF2 masks [15].

The effectiveness of face shields depends on the quality of the visor, its structure, and the fixation system, as well as applying the correct methods for removal and cleaning. The visor can be manufactured from various types of materials, including polycarbonate, propionate, acetate, polyvinyl chloride, and polyethylene glycol terephthalate, which are supplied in disposable, reusable, and replaceable models for the determined service lifetime of the equipment [20]. To avoid reflection and refraction of light 
Table 2

Distribution of selected studies

\begin{tabular}{|c|c|c|c|c|c|}
\hline Authors, Year & Title & Objective & Type of study & $\begin{array}{l}\text { Level of } \\
\text { evidence }\end{array}$ & Results \\
\hline $\begin{array}{l}\text { Williams et al. } \\
\text { [11], } 2019\end{array}$ & $\begin{array}{l}\text { Improving healthcare worker adherence to the } \\
\text { use of transmission-based precautions } \\
\text { through application of human factors } \\
\text { design: a prospective multi-center study }\end{array}$ & $\begin{array}{l}\text { To apply a human factor-based improvement } \\
\text { strategy to improve health professionals' } \\
\text { compliance with the use of personal } \\
\text { protective equipment. }\end{array}$ & $\begin{array}{l}\text { Multicenter } \\
\text { observational } \\
\text { prospective }\end{array}$ & IV & $\begin{array}{l}\text { The placement of equipment by professionals } \\
\text { has improved significantly; signage in an } \\
\text { appropriate location has improved } \\
\text { adherence to the use of PPE; replacing eye } \\
\text { goggles with a face mask with integrated } \\
\text { face protection has improved adhesion. }\end{array}$ \\
\hline $\begin{array}{l}\text { Walton et al. } \\
{[12], 2019}\end{array}$ & $\begin{array}{l}\text { Nursing assistants' use of personal protective } \\
\text { equipment regarding contact with excreta } \\
\text { contaminated with antineoplastic drugs }\end{array}$ & $\begin{array}{l}\text { To determine the feasibility of observing and } \\
\text { interviewing nursing assistants on the safe } \\
\text { handling of antineoplastic drugs } \\
\text { contaminated with excrement and } \\
\text { examining the acceptability of a measure } \\
\text { for personal protective equipment (PPE) use } \\
\text { by auxiliaries and predictor of PPE use. }\end{array}$ & $\begin{array}{l}\text { Descriptive } \\
\text { cross-section }\end{array}$ & VI & $\begin{array}{l}\text { The observed use of double gloves, } \\
\text { chemotherapy aprons and face shields was } \\
\text { low; the use of plastic pads for excreta } \\
\text { discharge was high. Only half of the nursing } \\
\text { assistants received training in the use of } \\
\text { PPE. Policies for safe handling of PPE, fear } \\
\text { of exposure to antineoplastic drugs were } \\
\text { some predictors of PPE use. }\end{array}$ \\
\hline $\begin{array}{l}\text { Loibner et al. } \\
\text { [13], } 2019\end{array}$ & $\begin{array}{l}\text { Limiting factors for wearing personal } \\
\text { protective equipment (PPE) in a health care } \\
\text { environment evaluated in a randomized } \\
\text { study }\end{array}$ & $\begin{array}{l}\text { To investigate how the use of PPE influences } \\
\text { physical performance, individual } \\
\text { well-being, concentration, and error rates } \\
\text { (items processed incorrectly in different } \\
\text { tasks), by performing a series of different } \\
\text { tasks in a healthcare environment with a } \\
\text { temperature of } 22^{\circ} \mathrm{C} \text { and } 28^{\circ} \mathrm{C} \text {. }\end{array}$ & $\begin{array}{l}\text { Randomized } \\
\text { clinical trial }\end{array}$ & II & $\begin{array}{l}\text { The most restrictive factors were reduced } \\
\text { dexterity due to several layers of gloves, } \\
\text { visibility impaired by flexible face shields } \\
\text { and back pain related to the patient's } \\
\text { respirator, fully ventilated clothing. Thermal } \\
\text { stress and fluid loss were perceived as } \\
\text { restrictive at a working temperature of } 28^{\circ} \mathrm{C} \text {. }\end{array}$ \\
\hline $\begin{array}{l}\text { Phan et al. } \\
\text { [14], } 2019\end{array}$ & $\begin{array}{l}\text { Respiratory viruses on personal protective } \\
\text { equipment and bodies of healthcare workers }\end{array}$ & $\begin{array}{l}\text { To characterize the magnitude of virus } \\
\text { contamination in personal protective } \\
\text { equipment (PPE), skin and clothing of } \\
\text { health professionals caring for patients with } \\
\text { acute viral infections. }\end{array}$ & $\begin{array}{l}\text { Prospective } \\
\text { observational }\end{array}$ & IV & $\begin{array}{l}31 \% \text { of the glove samples, } 21 \% \text { of the } \\
\text { clothing samples, and } 12 \% \text { of the mask } \\
\text { samples were virus positive. Among body } \\
\text { and clothing locations, } 21 \% \text { of bare hand } \\
\text { samples, } 11 \% \text { of exfoliation samples and } \\
7 \% \text { of face samples were virus positive. } \\
\text { Virus concentrations in the masks were } \\
\text { positively correlated with the number of } \\
\text { contacts with the mask and with the } \\
\text { patients. The presence of viruses on the } \\
\text { hands under the gloves, face and apron of } \\
\text { the professionals indicates that the PPE } \\
\text { used did not offer barrier protection and/or } \\
\text { that self-contamination occurred. }\end{array}$ \\
\hline
\end{tabular}

(Continued) 
Table 2

(Continued)

\begin{tabular}{|c|c|c|c|c|c|}
\hline Authors, Year & Title & Objective & Type of study & $\begin{array}{l}\text { Level of } \\
\text { evidence }\end{array}$ & Results \\
\hline $\begin{array}{l}\text { Lindsley et al. } \\
\text { [15], } 2014\end{array}$ & $\begin{array}{l}\text { Efficacy of face shields against cough aerosol } \\
\text { droplets from cough simulator }\end{array}$ & $\begin{array}{l}\text { To quantify healthcare professionals' } \\
\text { exposure to aerosol droplets eliminated by } \\
\text { coughing and examine the effectiveness of } \\
\text { face shields in reducing such exposure }\end{array}$ & $\begin{array}{l}\text { Non-randomized } \\
\text { clinical trial }\end{array}$ & III & $\begin{array}{l}0.9 \% \text { of the initial aerosol explosion of a } \\
\text { cough can be inhaled by a worker at } 46 \mathrm{~cm} \\
\text { from the patient. The use of a face shield } \\
\text { reduced the worker's inhalation exposure by } \\
96 \% \text { in the immediate period after the } \\
\text { cough. When a minor cough aerosol was } \\
\text { used (VMD }=3.4 \mu \mathrm{m} \text { ), the face shield was } \\
\text { less effective, blocking only } 68 \% \text { of the } \\
\text { cough and } 76 \% \text { of surface contamination. In } \\
\text { the period from } 1 \text { to } 30 \text { minutes after a } \\
\text { cough, the face shield reduced aerosol } \\
\text { inhalation by only } 23 \% \text {. Face shields can } \\
\text { substantially reduce the short-term exposure } \\
\text { of healthcare professionals. }\end{array}$ \\
\hline $\begin{array}{l}\text { Gozel et al. } \\
\text { [16], } 2013\end{array}$ & $\begin{array}{l}\text { Recommend precaution procedures protect } \\
\text { healthcare workers from Crimean-Congo } \\
\text { hemorrhagic fever virus }\end{array}$ & $\begin{array}{l}\text { To investigate the compliance of health } \\
\text { professionals with the use of personal } \\
\text { protective equipment (PPE) during the } \\
\text { follow-up of patients with the hemorrhagic } \\
\text { fever virus and determine the seroprevalence } \\
\text { of the virus in these professionals. To } \\
\text { highlight the adoption of eye protection by } \\
\text { all clinical staff and patients in the context } \\
\text { of general dental practice. }\end{array}$ & Cohort & IV & $\begin{array}{l}\text { Total seropositivity for the hemorrhagic fever } \\
\text { virus was only } 0.53 \% \text {, a rate considered low. } \\
\text { This was the result of the high compliance } \\
\text { of health professionals with the use of PPE. }\end{array}$ \\
\hline $\begin{array}{r}\text { Farrier et al. } \\
{[17], 2006}\end{array}$ & $\begin{array}{l}\text { Eye safety in operative dentistry - A study in } \\
\text { general dental practice }\end{array}$ & $\begin{array}{l}\text { To highlight the adoption of eye protection by } \\
\text { all clinical staff and patients in the context } \\
\text { of general dental practice. }\end{array}$ & $\begin{array}{l}\text { Descriptive } \\
\text { cross-section }\end{array}$ & VI & $\begin{array}{l}87 \% \text { of professionals used eye protection } \\
\text { routinely, but the choice of protection was } \\
\text { not always adequate and was not always } \\
\text { used in all procedures. } 48 \% \text { experienced } \\
\text { trauma or eye infection that occurred during } \\
\text { a variety of procedures; } 75 \% \text { of these } \\
\text { injuries resulted from not wearing eye } \\
\text { protection. Damage can be reduced by } \\
\text { improving adherence to adequate eye } \\
\text { protection. }\end{array}$ \\
\hline
\end{tabular}


and consequent eye fatigue, it is recommended that the visor material is made of polycarbonate, acetate, and propionate [13]. However, polyethylene glycol terephthalate displays are the most economical [21].

Recommendations for face shield visor size include being wide enough to reach at least the tip of the ear and should offer chin protection [22]. Wider displays offer greater peripheral protection for enhanced infection-control purposes [19]. However, these should not limit neck rotation movements and thereby decrease the quality of patient care [20]. In an experimental study carried out with the head of a mannequin, equipped with various types of PPE, a face shield with head/neck length, three separate points of contact on the forehead, and a lateral curve reaching the tip of the ear, or a combination of this face shield and an N95 filter face mask respirator (PFF2), protected the eyes, nostrils, and mouth from possible contamination [23].

The fixation system should be made of lightweight plastic and can be of an adjustable type. Metal frames are available that are designed to attach a face mask to prescription glasses [24]. Face shields with a foam pad on the forehead in the attachment system provide a comfortable seal, but in the context of the COVID-19 pandemic, this type of face shield should be rigorously evaluated in light of the cleaning process after its use [5, 25].

As for the sanitization process, face shields must be subjected to cleaning processes, with water and soap/hospital detergent, and should be disinfected. The use of a ratio of $70 \%$ alcohol, and $1 \%$ sodium hypochlorite, or other disinfectants recommended by manufacturers that are compatible with the equipment material, is suggested for disinfection $[6,26]$. In an experimental study, North American researchers identified that pulse disinfection by xenon ultraviolet (PX-UV) for face shields reduced the levels of virus contamination, which may be an additional alternative for the cleaning and disinfection process [27].

Furthermore, the selection of the most appropriate facial protection model will depend on the circumstances of exposure, the other PPEs used simultaneously, and the need for accurate visibility for the professional who will be using the protection [28]. Face shields with only Velcro ${ }^{\circledR}$ or elastic strips tend to be easier to put on, and removal can be performed with a single hand. To be effective, face shields must be firmly adjusted to ensure a good seal in the forehead area to prevent the shield from slipping out of position [19, 29].
Another aspect to consider is ensuring an adequate space between the user's face and the internal surface of the display to allow the use of other PPE such as N-95/surgical masks, and goggles. [28]. The use of a face shield alone for facial protection against SARS$\mathrm{CoV}-2$ is probably insufficient; it should not be used for respiratory protection, much less replace it, and should be used simultaneously with other forms of protection $[14,15,30]$.

In cases where there is a possibility of aerosolization of body fluids from infected individuals such as airway suction, intubation, and cardio-respiratory resuscitation, an N-95 or a PFF2 mask must be used $[16,23]$. Using an aerosol cough simulator loaded with influenza viruses and a breathing simulator, researchers reported reductions of $96 \%$ and $92 \%$, respectively, in the risk of inhalation exposure immediately after a cough with the use of a face shield [15].

Human costs are increasing, and the lack of PPE, a lack of planning for public health emergencies associated with high viral load, and its rapid transmissibility require a more efficient organizational and decisionmaking structure, compatible with the urgency of combating the pandemic. Complications resulting from the use of face shields during the COVID-19 epidemic are possible. Therefore, the researchers recommend the use of adhesive dressings on the skin for prevention. For example, creams and ointments can be used in the presence of eczema on the face [31-34].

Moreover, aspects related to the type of assistance provided by health professionals should be pointed out regarding the choice of a face shield. The dynamics of the type of work, its organization, and its specific characteristics must be considered when evaluating face shields.

The research was carried out at the beginning of the pandemic which can be regarded as a limitation in the study. The studies that were included do not provide evidence directly related to the context of the pandemic, which could lead to information bias. However, face shields are a PPE indicated for respiratory protection, regardless of the etiological agent.

\section{Conclusion}

This integrative review enabled the search for scientific evidence on the use of face shields for infection control purposes to assist in the selection and proper use of this type of PPE. 
The available evidence, although scarce, shows that face shields do not have a defined standard regarding their manufacture. Some care is essential, and the professional must pay attention to the type of hospital activity, decreased visual acuity (use of spectacles), and particularities of head and neck anatomy. Due to the fragilities of the peripheral facial seal that may allow aerosol penetration, face shields should be used as an adjunct to other protective masks (PPEs), and their isolated use is not recommended, especially during the COVID-19 pandemic period.

The difficulty of acquisition at this time can be solved through the purchase of domestic face shields, provided that they meet the minimum protection requirements for which the face shield is intended. Therefore, health professionals and/or health institutions should gather scientific evidence about the different forms of facial protection recommended by the WHO and acquire appropriate equipment that meets these recommendations, as well as the type of assistance provided.

\section{Approval of the research ethics committee}

This work did not undergo ethical analysis and evaluation due to the nature of the study.

\section{Conflict of interest}

The authors declare that there is no conflict of interest.

\section{Funding}

This work did not receive any funding.

\section{References}

[1] WHO. Infection prevention and control during health care for probable or confirmed cases of Middle East respiratory syndrome coronavirus (MERS- $\mathrm{CoV}$ ) infection: Interim guidance. World Health Organization; 2020. Available from: https://apps.who.int/iris/bitstream/handle/10665/ 174652/WHO_MERS_IPC_15.1_eng.pdf;jsessionid=A0E0 E19E965F934AD04E2E495BB1D48F? sequence=1.

[2] WHO. Coronavirus (COVID-19) Dashboard. World Health Organization; 2021, June 1. Available from: https://www. who.int/docs/default-source/coronaviruse/situationreports/20200709-covid-19-sitrep-171.pdf?sfvrsn=9aba 7 ec7_2.
[3] Shereen MA, Khana S, Kazmi A, Bashir N, Siddique R. COVID-19 infection: Origin, transmission, and characteristics of human coronaviruses. Journal of Advanced Research. 2020;24:91-8.

[4] Hersi M, Stevens A, Quach P, Hamel C, Thavorn K, Garritty $\mathrm{C}$, et al. Effectiveness of personal protective equipment for healthcare workers caring for patients with filovirus disease: a rapid review. PLoS ONE. 2015;10(10).

[5] WHO. Requirements and technical specifications of personal protective equipment (PPE) for the novel coronavirus (2019-ncov) in healthcare settings. Interim recommendations. World Health Organization; 2020. Available from: https://iris.paho.org/bitstream/handle/10665.2/51906/requi rements-\%20PPE-coronavirus-eng.pdf? sequence $=1 \&$ is Allowed=y.

[6] Centers for Disease Control and Prevention. Strategies to Optimize the Supply of PPE and Equipment. 2020. Available from: https://www.cdc.gov/coronavirus/2019-ncov/ hcp/ppe-strategy/index.html.

[7] Whittemore R, Chao A, Jang M, Minges KE, Park C. Methods for knowledge synthesis: an overview. Heart Lung. 2014;43(5):453-61.

[8] Lira RPC, Rocha EM. PICOT: Imprescriptible items in a clinical research question. Arquivos Brasileiros de Oftalmologia. 2019;82(2):1-1.

[9] Moher D, Liberati A, Tetzlaff J. The PRISMA Group. Preferred reporting items for systematic reviews and meta-analyses: the PRISMA Statement. PLoS Medicine. 2009;6(7).

[10] Melnyk BM, Fineout-Overholt E. Evidence-based practice in nursing and health: a guide to best practice. Philadelphia: Wolters Kluwer; Lippincott Williams \& Wilkins Health; 2011.

[11] Williams VR, Leis JA, Trbovich P, Agnihotri T, Lee W, Joseph B, et al. Improving healthcare worker adherence to the use of transmission-based precautions through application of human factors design: a prospective multi-centre study. Journal of Hospital Infection. 2019;103:101-5.

[12] Walton AL, Kneipp S, Linnan L, Asafu-Adjei J, Douglas C, Leff M, et al. Nursing assistants' use of personal protective equipment regarding contact with excreta contaminated with antineoplastic drugs. Oncology Nursing Forum. 2019;46(6):689-700.

[13] Loibner M, Hagauer S, Schwantzer G, Berghold A, Zatloukal K. Limiting factors for wearing personal protective equipment (PPE) in a health care environment evaluated in a randomized study. PLoS ONE. 2019;14(1).

[14] Phan LT, Sweeney D, Maita D, Moritz DC, Bleasdale SC, Jones RM. Respiratory viruses on personal protective equipment and bodies of healthcare workers. Infection Control \& Hospital Epidemiology. 2019;40:1356-60.

[15] Lindsley WG, Noti JD, Blachere FM, Szaladja JV, Beezhold DH. Efficacy of face shields against cough aerosol droplets from a cough simulator. Journal of Occupational Environmental Hygiene. 2014;11(8):509-18.

[16] Gozel MG, Dokmetas I, Oztop AY, Engin A, Elaldi N, Bakir M. Recommended precaution procedures protect healthcare workers from Crimean-Congo hemorrhagic fever virus. International Journal of Infectious Diseases. 2013;17(11).

[17] Farrier SL, Farrier JN, Gilmour ASM. Eye safety in operative dentistry - A study in general dental practice. Brazilian Dental Journal. 2006;200:218-23.

[18] WHO. How to put on and take off personal protective equipment (PPE). World Health Organization; 2008. Available from: https://apps.who.int/iris/bitstream/handle/10665/700 
66/WHO_CDS_EPR_2007.8a_eng.pdf?sequence=1\&isAll owed=y.

[19] Beckerdite K. Eye \& face protection. Overcome the challenges to using face shields. 2012. Available from: https:// www.ishn.com/articles/94033-eye-face-protection.

[20] Association of Surgical Technologists. AST Guidelines for best practices in use of eye protection during surgical procedures. 2017. Available from: http://www.ast.org/ uploadedFiles/Main_Site/Content/About_Us/ASTGuidelin esEyeProt ection.pdf.

[21] Grainger WW. QuickTips Technical Resources: "Quick Tip \#373. Face shield Protection". 2018. Available from: http:// www.grainger.com/content/qt-face-shield-protection-373.

[22] Centers for Disease Control and Prevention. Workplace Safety \& Health Topics. Eye Protection for Infection Control. 2020. Available from: https://www.cdc.gov/niosh/ topics/eye/eye- infectious.html.

[23] Shoham S, Acuna-Villaorduna C, Cotton M, Hardwick M. Comparison of Protection against Ocular Contamination with Disposable Eyewear Products. Washington Hospital Center. 2010. Available from: http://www.medonyx.com/ media/MedStarFullClinicalPoster.pdf.

[24] Lipp A. The effectiveness of surgical face masks: what the literature shows. Nurs ing Times. 2003;99:22-4.

[25] International Safety Equipment Association. Eye and face protection: selection and use guide. 2016. Available from: https://safetyequipment.org/wp-content/uploads/2015/05/ ISEA-EF- 2016-Selection-and-Use-1.pdf.

[26] Centers for Disease Control and Prevention. Interim Clinical Guidance for Management of Patients with Confirmed Coronavirus Disease (COVID-19). Infection Control: Severe acute respiratory syndrome coronavirus 2 (SARSCoV-2). 2020. Available from: https://www.cdc.gov/corona virus/2019-ncov/hcp/clinical-guidance-managementpatients.html.
[27] Jinadatha C, Simmons S, Dale C, Ganachari-Mallapa N, Villamaria FC, Goulding N, et al. Disinfecting personal protective equipment with pulsed xenon ultraviolet as a risk mitigation strategy for health care workers. American Journal of Infection Control. 2015;43(4):412-4.

[28] Loveridge JM, Gozzard C, Bannister GC. The effectiveness of a visor as a surgical barrier: an inverted position is better. Journal of Hospital Infection. 2005;62:251-53.

[29] Rosskam E. A 21st century approach to assessing the protection of workers' health. Work. 2011;38(3):265-78.

[30] Leonard RH, Crawford JJ. Infection Control. In: Heymann HO, Swift EJ, Ritter EV. editors. Sturdevant's Art and Science of Operative Dentistry. Page-burst E-book on Vital Source. 6d Maryland Heights; 2013:98-129.

[31] Huh S. How to train health personnel to protect themselves from SARS-CoV-2 (novel coronavirus) infection when caring for a patient or suspected case. Journal of Educational Evaluation for Health Professions. 2020;17:20.

[32] Pniak B, Leszczak J, Adamczyk M, Rusek W, Matłosz P, Guzik A. Occupational burnout among active physiotherapists working in clinical hospitals during the COVID19 pandemic in south-eastern Poland. Work. 2021;68(2): 285-95.

[33] Soares EB. Organizational issues that impact on non-use of equipment for individual protection: a view of ergonomics. Work. 2012;41 Suppl 1:2668-74.

[34] Makowski K, Okrasa M. Application of 3D scanning and 3D printing for designing and fabricating customized half-mask facepieces: A pilot study. Work. 2019;63(1):125- 35 . 